\title{
The Effects of Orthodontic Forces during Canine Retraction Using Self-ligating Brackets on Gingival Crevicular Fluid Enzyme Activity, Canine Movement and Root Resorption
}

(Kesan Daya Ortodontik semasa Retraksi Gigi Kanin Menggunakan Braket Swa-Peligaturan ke atas Aktiviti Enzim Cecair Krevis Gingiva, Pergerakan Gigi dan Penyerapan Akar)

\author{
Rohaya Megat Abdul WahaB*, Zulham Yamamoto, Albira Sintian, NurfathiHa Abu Kasim, \\ INTAN ZARINA ZAINOL ABIDIN, SAHIDAN SENAFI, ZAIDAH ZAINAL ARIFFIN \\ \& SHAHRUL HISHAM ZAINAL ARIFFIN
}

\begin{abstract}
Alkaline phosphatase (ALP), tartrate-resistant acid phosphatase (TRAP) and aspartate aminotransferase (AST) activities were studied as biomarkers of canine movement. Root resorption was also evaluated in canines subjected to the orthodontic forces. Nineteen subjects randomly received 100 and $150 \mathrm{~g}$ force using self-ligating brackets (SLB) either on the right or left site of maxillary arch. Gingival crevicular fluid samples were collected at distal sites of canines for five consecutive weeks. The activities of ALP, TRAP and AST were assayed and measured spectrophotometrically. Canine movement was measured for five consecutive weeks while root resorption was monitored at baseline, week 0 and week 5 using periapical radiographs. In $100 \mathrm{~g}$ group, TRAP activity significantly increased in week 3-5 when compared to TRAP baseline activity. However, ALP and AST activities slightly increased. In $150 \mathrm{~g}$ group, ALP and TRAP activities slightly increased when compared with their baseline activities. However, AST significantly increased in week 5. Canine movement and root resorption were not significantly different $(\mathrm{p}<0.05)$ in both groups. A force of 100 and $150 \mathrm{~g}$ slightly increased the bone modeling process and resulted in similar canine movement and root resorption. Therefore, $100 \mathrm{~g}$ force could be an optimum force for canine retraction and is preferable (compared with $150 \mathrm{~g}$ force) in canine retraction using SLB.
\end{abstract}

Keywords: Alkaline phosphatase; aspartate aminotransferase; biomarker; self-ligating bracket; tartrate-resistant acid phosphatase; tooth movement

\section{ABSTRAK}

Aktiviti alkalin fosfatase (ALP), asid fosfatase rintang tartarat (TRAP) dan aspartat aminotransferase (AST) telah dikaji sebagai penanda biologi bagi pergerakan gigi kanin. Penyerapan akar juga dinilai pada gigi kanin yang dikenakan daya ortodontik. Sembilan belas subjek secara rawak menerima daya 100 dan 150 g menggunakan braket swa-peligaturan (SLB) samada pada kanan atau kiri lengkung rahang atas. Sampel cecair krevis gingiva (GCF) dikumpul daripada tapak distal gigi kanin selama 5 minggu berturut-turut. Aktiviti ALP, TRAP dan AST diasai dan diukur menggunakan spektrofotometer. Pergerakan gigi kanin diukur setiap minggu selama 5 minggu, manakala penyerapan akar diperhatikan pada sebelum rawatan, minggu 0 dan minggu 5 menggunakan radiograf periapikal. Bagi kumpulan $100 \mathrm{~g}$, aktiviti TRAP meningkat secara signifikan pada minggu 3-5 apabila dibandingkan dengan aktiviti TRAP sebelum rawatan. Namun, aktiviti ALP dan AST hanya mengalami sedikit peningkatan. Bagi kumpulan $150 \mathrm{~g}$ pula, aktiviti ALP dan TRAP meningkat sedikit apabila dibandingkan dengan aktiviti masing-masing sebelum rawatan. Walau bagaimanapun, aktiviti AST didapati meningkat secara signifikan pada minggu ke-5. Pergerakan dan penyerapan akar gigi kanin didapati tidak berbeza secara signifikan $(\mathrm{p}<0.005)$ bagi kedua-kedua kumpulan. Daya 100 dan $150 \mathrm{~g}$ hanya menyebabkan sedikit peningkatan dalam proses pembentukan tulang dan seterusnya menghasilkan pergerakan dan penyerapan akar gigi kanin yang sama. Oleh itu, daya $100 \mathrm{~g}$ boleh menjadi daya optimum untuk retraksi gigi kanin dan lebih menjadi pilihan (berbanding daya $150 \mathrm{~g}$ ) dalam retraksi gigi kanin menggunakan $S L B$.

Kata kunci: Alkalin fosfatase; asid fosfatase rintang tartarat; aspartat aminotransferase; braket swa-peligaturan; penanda biologi; pergerakan gigi

\section{INTRODUCTION}

In order to move the teeth, orthodontic treatment requires an optimum force. This optimum force should result in maximum rate of tooth movement with minimum irreversible damage (Ren et al. 2004). Several studies recommended a $150 \mathrm{~g}$ as the optimum force for canine retraction (Mezomo et al. 2011; Rohaya et al. 2011).

During orthodontic treatment, orthodontic force results in alveolar bone modeling that are represented by alveolar bone resorption in the compression side and 
bone formation in the tension side (Seibel 2005). This modeling process was used for investigating enzymes activities collected from gingival crevicular fluid (GCF) (Asma et al. 2011; Perinetti et al. 2002; Rohaya et al. 2011, 2008). GCF is exudates found in the gingival sulcus containing host derived substances ( $\mathrm{Ru}$ et al. 2013) and its composition relates to changes in the periodontium (Dudic et al. 2006; Shah 2011; Singer \& Eyre 2008). GCF alkaline phosphatase (ALP) (Asma et al. 2008), tartrateresistant acid phosphatase (TRAP) (Rohaya et al. 2011) and aspartate aminotransferase (AST) (Shahrul Hisham et al. 2011) were suggested to be biomarkers to monitor alveolar bone modeling, tooth movement and predictor of the treatment responses.

ALP is produced by cells within the periodontium and diffuses into the GCF (Perinetti et al. 2003). Bone cells involved in bone formation, i.e. osteoblasts, have an ALP activity (Rohaya et al. 2011; Yamaguchi et al. 1996). During bone formation, increased osteoblasts activity is accompanied by higher ALP expression (Intan Zarina et al. 2008). To date, it is known that alveolar bone modelling correlates with changes in GCF phosphatase activities (Insoft et al. 1996) and the rate of bone formation can be influenced by ALP activity (Asma et al. 2011; Batra et al. 2006). ALP activity elevates higher at the tension site than the compression site (Perinetti et al. 2002) since the tension site resuts in bone formation, while compression site results in bone resorption (Roberts-Harry \& Sandy 2004; Seibel 2005).

TRAP is an osteoclast biomarker (Intan Zarina et al. 2008; Shahrul Hisham et al. 2011) and can be used to determine osteoclast activity during orthodontic treatment. TRAP activity increases proportionally with the orthodontic force magnitude (Rohaya et al. 2011).

AST is released to extracellular environment upon cell death (Meeran 2012). The activity of AST is important in regulating alveolar bone resorption during orthodontic tooth movement (OTM) (Meeran 2012). Therefore, AST has potential as a diagnostic aid to monitor tooth movement and tissue responses during orthodontic treatment (Perinetti et al. 2003).

Mechanical phenomena produced by various bracket and archwire types should contend with periodontal biological barriers to result in orthodontic movement (Burrow 2010). Self-ligating brackets (SLB) eliminate the issue of force decay from elastomeric ligatures and uneven strength of ligation produced by steel ligatures. To date, there are no presenting studies comparing the effect of different continuous force to the enzymes activities as biomarkers of tooth movement during canine retraction. This study aimed to investigate the activities of ALP, TRAP and AST in GCF during maxillary canine movement and the amount of canine root resorption under two continuous orthodontic forces.

\section{MATERIALS AND METHODS}

\section{STUDY DESIGN AND POPULATION}

This is a prospective study. Nineteen healthy subjects, 13 females and 6 males (aged 16 to 28 ; mean 21.3 \pm 3.3 years), seeking orthodontic treatment in the Orthodontic Clinic, Faculty of Dentistry, Universiti Kebangsaan Malaysia, participated in this study. Subjects were consecutively sampled using inclusion criteria as follows: Healthy subjects without any systemic disease(s); have good oral hygiene and periodontal health; not pregnant; nonsmoker; have mild to moderate crowding of the maxillary and mandibular arches that require extraction of upper first premolars; have canine relationship of class II $1 / 2$ unit or more; have class II/1 incisal relationship with an overjet of more than $6 \mathrm{~mm}$; have an overbite of not more than 50\%; have no previous orthodontic or orthopedic treatment; and have no craniofacial anomalies. Optimal oral health was achieved in all subjects prior to the study. During the study period, subjects were not allowed to take any anti-inflammatory drugs and mouthwashes containing chlorhexidine. Informed consent was obtained from the patient or the parent or guardian prior to the commencement. The research protocol was approved by the Research Ethical Committee of Universiti Kebangsaan Malaysia (No:1.5.3.5/244/SPP/DD/030 (1)/2010).

\section{ORTHODONTIC APPLIANCE AND EXPERIMENTAL TEETH}

The pre-adjusted Straight-Wire SLBs (Forestadent, Quick Bracket; MBT prescription) with $0.022^{\prime \prime} \times 0.028^{\prime \prime}$ slots were bonded to the buccal surface of the maxillary teeth after a transpalatal arch with Nance button was cemented to the maxillary first molars. The initial alignment was obtained with a 0.014" Cuprum-Nickel-Titanium (CuNiTi) archwire (Biostarter, Forestadent). The leveling and alignment stages were completed in three to four consecutive visits using $0.018^{\prime \prime} \times 0.025^{\prime \prime} \mathrm{CuNiTi}$ archwire (Biotorque, Forestadent). The working archwire of $0.019^{\prime \prime} \times 0.025^{\prime \prime}$ stainless steel (SS) (TrueForce, Ormco, USA) was inserted and left in situ for four weeks to allow passivity of the archwire before proceeding to canine retraction stage. Canine retraction was performed on $0.019^{\prime \prime} \times 0.025^{\prime \prime}$ SS using light nickel titanium (NiTi) eyelet closing coil spring (American Ortho, USA) hooked onto the brackets of maxillary canines and first molars. In a split-mouth design, the patient received 100 or $150 \mathrm{~g}$ force either on the right or left side of maxillary arch, determined through random allocation using a coin toss method. The force applied was measured using Correx gauge (Dial-type stress and tension gauge; Dentaurum Germany).

\section{GCF SAMPLING AND ENZYME ASSAYS}

GCF was collected using Periopaperä strips (Proflow, USA) at baseline (week 0) and five consecutive weeks (week 1 to week 5) of canine retraction stage. The GCF samples were 
collected at the distal sites of the maxillary canines. Three strips were used with $1 \mathrm{~min}$ interval. Each strip was inserted $1-2 \mathrm{~mm}$ in the gingival crevice and left in situ for $60 \mathrm{~s}$.

The three dipped strips were placed into a microtube containing $80 \mu \mathrm{L}$ physiological saline and subsequently diluted with $1200 \mathrm{~mL}$ of $100 \mathrm{mg} / \mathrm{mL}$ bovine serum albumin. The microtube was centrifuged at $4^{\circ} \mathrm{C}$ for 10 min at $1300 \mathrm{~g}$ using a microcentrifuge machine (Hettich Zentrifugen Mikro 22Rä). Supernatant was analyzed for ALP, TRAP and AST assays immediately while Bradford assay was performed to determine the total protein content in the diluted GCF samples.

\section{ALKALINE PHOSPHATASE ASSAY}

A total of $10 \mu \mathrm{L}$ of diluted GCF sample was added into a solution containing $10 \mathrm{mM}$ p-nitrophenyl phosphate (PNPP), $100 \mathrm{mM}$ carbonate buffer (pH9.8), 3 mM MgCl and $200 \mathrm{mM}$ mannitol. The solutions were incubated for $30 \mathrm{~min}$ at $30^{\circ} \mathrm{C}$. ALP hydrolyses the PNPP into p-nitrophenol and inorganic phosphate. The reactions were terminated by adding $50 \mathrm{~mL} 400 \mathrm{mM} \mathrm{NaOH}$. The blank consisted of the substrates and buffer without any GCF sample. The absorbance was determined at $405 \mathrm{~nm}$ using a microplate reader (Varioskanä, Thermofisher). Using serial dilutions of $10 \mathrm{mM}$ p-nitrophenol absorptivity; the absorbance was converted into enzymatic activity unit ( $1 \mathrm{U}$ equals to 1 $\mu \mathrm{mol}$ of p-nitrophenol released per minute at $30^{\circ} \mathrm{C}$ ) and expressed as ALP specific activity.

\section{TARTRATE-RESISTANT ACID PHOSPHATASE ASSAY}

A total of $10 \mu \mathrm{L}$ diluted GCF sample was mixed into a solution containing 1\% (v/v) Triton X-100, $100 \mathrm{mM}$ PNPP, $100 \mathrm{mM}$ acetate buffer (pH5.8), $0.15 \mathrm{mM} \mathrm{KCl}, 0.1 \mathrm{mM}$ $\mathrm{FeCl}_{3}, 10 \mathrm{mM}$ sodium tartrate and $1 \mathrm{mM}$ ascorbic acid. The solution was incubated for $30 \mathrm{~min}$ at $30^{\circ} \mathrm{C}$. The reactions were then terminated by adding $50 \mathrm{~mL} 900 \mathrm{mM} \mathrm{NaOH}$. The blank consisted of the substrates and buffer without any GCF sample. The absorbance was determined at 405 $\mathrm{nm}$ using a microplate reader (Varioskanä, Thermofisher). Using serial dilutions of $10 \mathrm{mM}$ p-nitrophenol absorptivity, the absorbance was converted into enzymatic activity unit and expressed as TRAP specific activity.

\section{ASPARTATE AMINOTRANSFERASE ASSAY}

A total of $25 \mu \mathrm{L}$ diluted GCF sample was mixed into a solution containing $150 \mathrm{mM}$ L-aspartate, $0.4 \mathrm{U}$ malate dehydrogenase, $0.2 \mathrm{mM}$ b-NADH ${ }^{+}, 100 \mathrm{mM}$ sodium phosphate buffer (pH7.5) and $100 \mathrm{mM}$ 2-oxoglutarate. The solution was incubated at $30^{\circ} \mathrm{C}$ for $5 \mathrm{~min}$. The change in absorbance at $340 \mathrm{~nm}$ using microplate reader (Varioskanä, Thermofisher) was monitored as the NADH was consumed. Conversion of the NADH to $\mathrm{NAD}^{+}$product was proportional to the level of AST enzyme in the sample. A value of $6.22 \times 10^{3}$ was considered as the NADH extinction coefficient. The results were converted into enzyme activity unit and expressed as AST specific activity.

\section{CANINE MOVEMENT MEASUREMENT}

An alginate impression was taken for study model construction before (week 0 ) and weekly for five consecutive weeks during the canine retraction period (week 1-5). Linear measurements from the distal margin of the bracket base to the mesial margin of the first molar band tube in the same quadrant were taken using a digital caliper (KERN, Germany).

\section{CANINE ROOT RESORPTION MEASUREMENT}

Periapical radiographs of maxillary canines were taken three times: Before orthodontic appliance placement $\left(R_{1}\right)$, after leveling and alignment, i.e. before canine retraction $\left(R_{2}\right)$ and 5 weeks after canine retraction $\left(R_{3}\right)$ using a paralleling technique.

The long cone paralleling technique was performed using the Sirona Heliodent Vario equipment $(7 \mathrm{~mA}, 70 \mathrm{kVp}$, $0.63 \mathrm{~s}$ ), an intraoral film (Kodak Insight, E speed, size $30.5 \times 40.5 \mathrm{~mm}$ ) and a paralleling device (Dentsply Rinn, Rinn Corporation, Elgin, IL, USA). The canine tip was placed at the centre of the bite block of the paralleling device to standardise the distance and angulation of the canine teeth at $\mathrm{R}_{1}, \mathrm{R}_{2}$ and $\mathrm{R}_{3}$ to minimise distortion of the image.

Tooth length in periapical radiographs were measured using digital calipers (KERN, German) at the best and constant point from root tip to the tip of the canine. Periapical root resorption was calculated from the difference between tooth length at $R_{1}$ and $R_{2}\left(R_{2}-R_{1}\right)$ and between $R_{1}$ and $R_{3}\left(R_{3}-R_{1}\right)$.

\section{STATISTICAL ANALYSIS}

All data were statistically analyzed using the SPSS ver. 20 . The data distribution was determined using the ShapiroWilk test. The differences between the two groups were tested using paired t-test. Enzyme activity at baseline acted as control.

\section{RESULTS}

\section{ALP, TRAP AND AST ACTIVITIES IN 100 G FORCE GROUP}

ALP activity slightly increased in the subsequent weeks after force application although it showed no significant differences $(p>0.05)$ compared with baseline (Table 1). TRAP activity showed significant differences $(p<0.05)$ at weeks 3 to 5 when compared with the baseline (Table 2). Other TRAP activities in subsequent weeks showed slightly increase activities and no significant differences $(p>0.05)$ when compared with TRAP baseline activity (Table 2). The AST activities showed slightly increase in the subsequent weeks after force application. However, there were no significant differences $(p>0.05)$ when compared with the AST baseline activities (Table 3 ). 


\section{ALP, TRAP AND AST ACTIVITIES IN 150 G FORCE GROUP}

There were slight increments in ALP activity from weeks 0 to 5 . However, no significant differences were observed $(p>0.05)$ (Table 1). Although TRAP activity increased after force application, the differences from baseline were insignificant (Table 2). When a $150 \mathrm{~g}$ force was applied, the AST activity peaked at week 5 and showed significant differences $(p<0.05)$ compared with AST baseline activity (Table 3).

TABLE 1. Mean GCF ALP activities at distal sites of retracted maxillary canines using 100 and $150 \mathrm{~g}$ force using SLB at baseline and weeks 0 to 5

\begin{tabular}{ccc}
\hline $\begin{array}{c}\text { Observation } \\
\text { week }\end{array}$ & \multicolumn{2}{c}{ Mean $\left(\times 10^{-8}\right) \pm \mathrm{SE}$} \\
& $100 \mathrm{~g}$ & $150 \mathrm{~g}$ \\
\hline Baseline & $1.67 \pm 0.06$ & $1.67 \pm 0.06$ \\
0 & $1.67 \pm 0.16$ & $1.74 \pm 0.23$ \\
1 & $1.93 \pm 0.17$ & $2.10 \pm 0.23$ \\
2 & $1.85 \pm 0.15$ & $1.94 \pm 0.23$ \\
3 & $1.67 \pm 0.24$ & $1.72 \pm 0.22$ \\
4 & $1.74 \pm 0.31$ & $2.08 \pm 0.46$ \\
5 & $1.94 \pm 0.33$ & $1.86 \pm 0.25$ \\
\hline
\end{tabular}

TABLE 2. Mean GCF TRAP activities at distal sites of retracted maxillary canines using 100 and $150 \mathrm{~g}$ force using SLB at baseline and weeks 0 to 5

\begin{tabular}{ccc}
\hline $\begin{array}{c}\text { Observation } \\
\text { week }\end{array}$ & \multicolumn{2}{c}{$\begin{array}{c}\text { Distal } \\
\end{array}$} \\
& $100 \mathrm{~g}$ & $150 \mathrm{~g}$ \\
\hline Baseline & $2.92 \pm 0.14$ & $2.92 \pm 0.14$ \\
0 & $3.09 \pm 0.19$ & $2.93 \pm 0.23$ \\
1 & $3.19 \pm 0.15$ & $3.38 \pm 0.38$ \\
2 & $3.37 \pm 0.21$ & $3.37 \pm 0.38$ \\
3 & $4.47 \pm 0.38$ & $4.44 \pm 0.34$ \\
4 & $3.89 \pm 0.43$ & $3.49 \pm 0.35$ \\
5 & $4.00 \pm 0.47$ & $3.63 \pm 0.39$ \\
\hline
\end{tabular}

TABLE 3. Mean GCF AST activities at distal sites of retracted maxillary canines using 100 and $150 \mathrm{~g}$ force using SLB at baseline and weeks 0 to 5

\begin{tabular}{ccc}
\hline $\begin{array}{c}\text { Observation } \\
\text { week }\end{array}$ & \multicolumn{2}{c}{ Distal site } \\
& $100 \mathrm{~g}$ & $150 \mathrm{~g}$ \\
\hline $\begin{array}{c}\text { Baseline }\left(\times 10^{-8}\right) \pm \mathrm{SE} \\
0\end{array}$ & $3.94 \pm 0.23$ & $3.94 \pm 0.23$ \\
1 & $4.95 \pm 0.40$ & $5.40 \pm 0.40$ \\
2 & $4.33 \pm 0.31$ & $5.31 \pm 1.50$ \\
3 & $4.47 \pm 0.30$ & $4.88 \pm 0.46$ \\
4 & $4.52 \pm 0.32$ & $5.01 \pm 0.61$ \\
5 & $4.96 \pm 0.43$ & $6.20 \pm 0.66$ \\
\hline
\end{tabular}

\section{ALP, TRAP AND AST ACTIVITIES COMPARISONS BETWEEN 100 AND 150 G FORCE GROUPS}

ALP activities in the $150 \mathrm{~g}$ group were slightly higher than the $100 \mathrm{~g}$ group at weeks 0 to 4 but the differences were not significant $(p>0.05)$ (Table 1). Meanwhile, TRAP activity was slightly higher in the $100 \mathrm{~g}$ group compared with the $150 \mathrm{~g}$ group from weeks 0 to 5 although they were not significantly different $(p>0.05)$ (Table 2$)$.

AST activity for both the 100 and $150 \mathrm{~g}$ groups showed similar increasing patterns during force application. AST activity appeared to be enhanced by the $150 \mathrm{~g}$ force but showed no significant differences $(p<0.05)$ between 100 and $150 \mathrm{~g}$ groups (Table 3 ).

\section{CANINE MOVEMENT}

The cumulative canine movement increased from week 0 to week 5 (Figure 1). The cumulative canine movement at the end of week 5 of the $100 \mathrm{~g}$ group was $1.24 \pm 0.29$ $\mathrm{mm}$ while the rate was $0.46 \pm 0.04 \mathrm{~mm}$ per week. In the $150 \mathrm{~g}$ group, the cumulative canine movement was 1.36 $\pm 0.39 \mathrm{~mm}$ while the rate was $0.47 \pm 0.05 \mathrm{~mm}$ per week. There was no significant difference $(\mathrm{P}>0.05)$ between the $100 \mathrm{~g}$ and $150 \mathrm{~g}$ groups in the rate of canine movement.

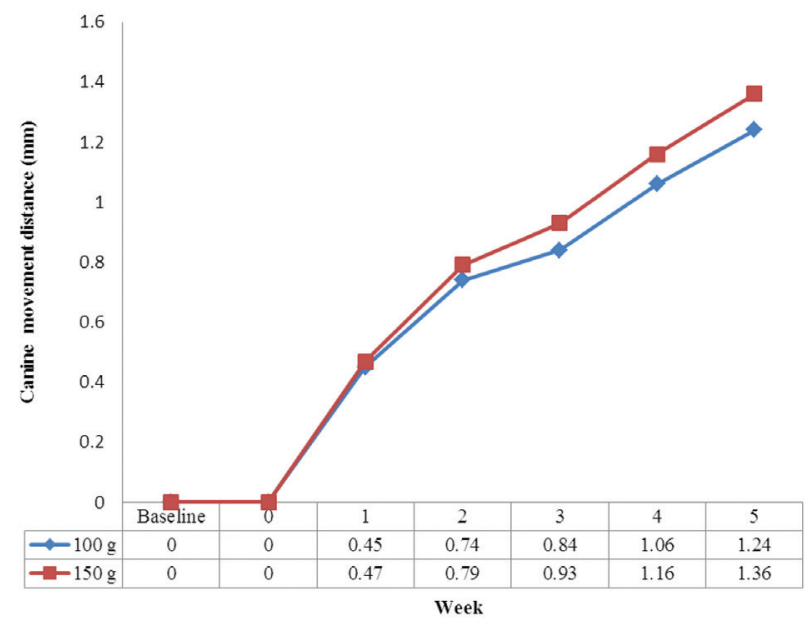

FIGURE 1. Cumulative of canine movement $(\mathrm{mm})$ with two different forces, 100 and $150 \mathrm{~g}$ using SLB, during 5 weeks post canine retraction

\section{CANINE ROOT RESORPTION}

There was no sign of root resorption at $\mathrm{R}_{1}$. Minimal signs of root resorption at $R_{2}(0.51$ and $0.52 \mathrm{~mm}$ with 100 and 150 $\mathrm{g}$, respectively) were observed. No apical root resorption with more than $1.50 \mathrm{~mm}$ was observed in the test teeth at $\mathrm{R}_{3}$ (Figure 2). A $150 \mathrm{~g}$ force produced more pronounced root resorption $(1.42 \pm 0.16 \mathrm{~mm})$ compared with $100 \mathrm{~g}$ force $(0.89 \pm 0.04 \mathrm{~mm}) 5$ weeks post canine retraction (Table 4$)$ although it was not significantly different $(p>0.05)$. 

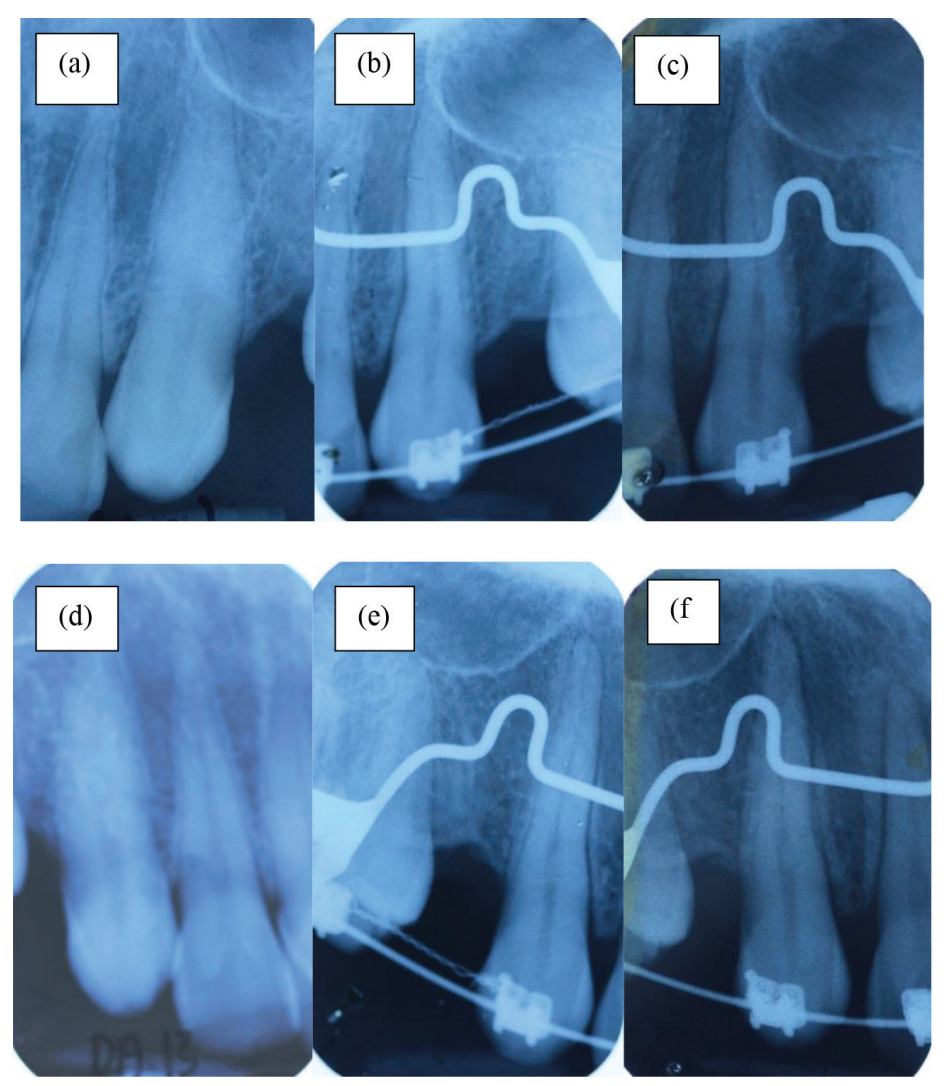

FIGURE 2. Periapical radiographs of retracted maxillary canines. (a), (b) and (c) show the same canine retracted using $150 \mathrm{~g}$ force and (d), (e) and (f) show the same canine retracted using $100 \mathrm{~g}$ force. From left to right: right before orthodontic appliance placement, before canine retraction, and 5 weeks after canine retraction

TABLE 4. Mean of total root resorption (mm) with 100 and $150 \mathrm{~g}$ force using SLB

\begin{tabular}{cccc}
\hline Orthodontic force & $\mathrm{R}_{1}$ & $\mathrm{R}_{2}$ & $\mathrm{R}_{3}$ \\
\hline $100 \mathrm{~g}$ & 0 & $0.51 \pm 0.09$ & $0.89 \pm 0.04$ \\
$150 \mathrm{~g}$ & 0 & $0.52 \pm 0.16$ & $1.42 \pm 0.13$ \\
\hline
\end{tabular}

\section{DISCUSSION}

\section{ORTHODONTIC APPLIANCE AND TEST TEETH}

A number of different orthodontic force systems are used to study OTM. Orthodontic force system includes bracket designs, archwires, elastics, bands, springs with different designs and coil springs with different materials. In the present study, the transpalatal arch with Nance button was placed to reinforce anchorage during canine retraction as to optimised canine retraction rather than mesialisation of maxillary molar (Stivaros et al. 2010). With anchorage reinforcement, the total of canine movement mostly came from canine retraction and not from molar movement.

In this study, prior to canine retraction, the $0.019^{\prime \prime} \times 0.025^{\prime \prime}$ SS archwire was left in situ for at least a month to allow full expression of torque and to ensure the passivity of archwire. This ensures that during canine retraction, maximum sliding mechanics were performed. The $0.019^{\prime \prime} \times 0.025^{\prime \prime} \mathrm{SS}$ promotes more bodily movement rather than tipping movement (Rohaya et al. 2011). The risk of root resorption is lesser in bodily movement compared with tipping movement due to stress distribution along the roots rather than to the stress concentration at the apex (Lopatiene \& Dumbravaite 2008). On the other hand, NiTi closed coil spring was used in this study due to its ability to deliver a constant orthodontic force.

\section{ALKALINE PHOSPHATASE ACTIVITIES DURING CANINE RETRACTION}

ALP was used as an indicator of bone formation (Singer \& Eyre 2008). Elevation of ALP activity indicates bone formation by osteoblast activity (Intan Zarina et al. 2008; Singer \& Eyre 2008). The ALP activities at baseline represented the continuous maintenance of the alveolar 
bone integrity in response to normal masticatory force. In the early stage of bone modelling, bone resorption occurs in 3-5 days followed by a reversal phase (5-7 days) and a late stage of bone deposition (7-14 days) occuring at tension and compression sites (Batra et al.2006). Upon light force application, periodontal ligament (PDL) is stretched in the tension area and vascularity is increased. This leads to the mobilisation of osteoclasts and fibroblasts to lay down osteoid bone immediately adjacent to the PDL (Shah 2011). With 100 and $150 \mathrm{~g}$ force ALP activity peaked at week 1 . However, both were not significantly different $(p>0.05)$ when compared to baseline activity. Using $100 \mathrm{~g}$ force, Batra et al. (2006) and Insoft et al. (1996) showed similar findings. Insoft et al. (1996) found that the ALP activity peaked between the first and third week (7-21 days) on premolar teeth, whereas Batra et al. (2006) found that ALP activities in canine retraction peaked at week 2 (day 14). Perinetti et al. (2004) exerted a higher force, i.e. $250 \mathrm{~g}$ on maxillary molar and found that ALP activity peaked at day 14. Therefore, the optimum force required (to move a tooth/ for bone remodeling/ for bone formation) varies according to the tooth type.

\section{TARTRATE-RESISTANT ACID PHOSPHATASE ACTIVITIES DURING CANINE RETRACTION}

The increase in TRAP activity is correlated with bone resorption especially in individuals with high bone turnover (Singer \& Eyre 2008). When there was no orthodontic force, TRAP activity was very minimal due to the normal remodelling process occurring in the bone (Bhosale et al. 2011). With this regard, we suggest that the baseline TRAP activity correspond to the normal/ physiological bone remodelling activity in response to masticatory forces.

In this study, TRAP activity peaked at week 3 in both groups. Upon orthodontic force application, TRAP activity increased throughout the observation period in conjunction with tooth movement. For a tooth to move, bone resorption must occur in the compression sites. The results of the present study indicated that bone resorption is active from week 1 and increases gradually. Enzymes associated with bone resorption increased their activity after $10 \mathrm{~h}$ of orthodontic force application (Lilja et al. 1983). In this study, TRAP activity showed significant increment at week 3 when compared with baseline (Table 3). Meeran (2012) stated that in the second phase of tooth movement, the osteoclasts attack the bone surface over a much wider area and result in bone resorption. This indicated that bone resorption was more predominant at distal/compression site compared to mesial site. Rohaya et al. (2011) found that during canine distalization using a $100 \mathrm{~g}$ force with conventional ligating brackets (CLB), a slight increase in TRAP activity was seen at week 3 in the tension site and peaked at week 5 in the compression site. When a $150 \mathrm{~g}$ force was applied, a slight increase in TRAP activity was observed at week 2 in the tension site and peaked at week 4 in the compression site (Rohaya et al. 2011).

\section{ASPARTATE AMINOTRANSFERASE ACTIVITIES DURING CANINE RETRACTION}

When a tooth is subjected to orthodontic force, the periodontal tissues will respond by becoming acutely inflamed due to cell necrosis and release various chemical mediators and enzymes. Extracellular AST presence is a sign of cell necrosis (Paolantonio et al. 2000). Although AST activity raised slightly as the force is increased, the difference was insignificant. This result is in agreement with Dannan et al. (2009), Perinetti et al. (2003) and Rohaya et al. (2008). During force application, we found that AST activity peaked at week 5 in both groups with $100 \mathrm{~g}$ group showing lower AST activity. Therefore, we suggest that $100 \mathrm{~g}$ force will give rise to less tissue damage compared with $150 \mathrm{~g}$ force. Tomizuka et al. (2007) found that gradually increased force resulted in less tissue damage (less hyalinization) compared with a heavier initial force that increased to the same end force level.

\section{CANINE MOVEMENT AND FORCE SYSTEM}

We used 100 and $150 \mathrm{~g}$ force to distalise maxillary canines with SLB. Using $150 \mathrm{~g}$ force, the rate of canine movement was almost similar when compared with $100 \mathrm{~g}$ force. Canine movement was fast at week 1 with the rate of 0.45 $\mathrm{mm}$ in $100 \mathrm{~g}$ group and $0.47 \mathrm{~mm}$ in $150 \mathrm{~g}$ group. However, this cumulative canine movement was slightly lower than the findings of other studies (Burrow 2010; Rohaya et al. 2011). Rohaya et al. (2011) used the same magnitude of force to distalise canine with CLB. They found that $150 \mathrm{~g}$ force resulted in a faster and significant cumulative tooth movement compared with $100 \mathrm{~g}$ force. Kilic et al. (2010) compared forces of 20 and $60 \mathrm{~g}$ in rabbit and reported higher force $(60 \mathrm{~g})$ produced faster tooth movement. These studies were in contrast with our findings since there was no significant difference $(p>0.05)$ between 100 and 150 $\mathrm{g}$ force in SLB.

The optimal force for canine movement were still in controversy. Rohaya et al. (2011) suggested that $150 \mathrm{~g}$ force could be an optimal force for canine distalization than $100 \mathrm{~g}$ force in CLB. Samuels et al. (1993) also found that $150 \mathrm{~g}$ force as the optimal force for space closure when using a NiTi coil springs although further increased force to $200 \mathrm{~g}$ gave no additional benefit in terms of rate of space closure. However, in a random split-mouth design study by Mezomo et al. (2011), canines movement that were retracted using elastic chain with $150 \mathrm{~g}$ force resulted in no difference of canines movement between SLB and CLB. This was in contrast with study by Burrow (2010), where the rate of canine retraction with $150 \mathrm{~g}$ force was faster in CLB compared to SLB. Therefore, different force magnitudes and different orthodontic force systems may contribute to these differences.

\section{ROOT RESORPTION}

Periapical radiographs were taken to monitor the root resorption of the test teeth. In clinical practice, the current recommendation is baseline periapical view pre-treatment 
or standard occlusal view with repeated views 6 to 9 months into treatment (Kindelan et al. 2008). In our study, we adopted Rohaya et al. (2011) methods in assessing root resorption for this study.

Six weeks of observation in this study was enough to detect any sign of root resorption as reported by Smale et al. (2005). They found that root resorption may be detected as early as the early stage of levelling and alignment period where the mean of root resorption was $0.53 \mathrm{~mm}$ and the mean of the most resorbed tooth was $1.18 \mathrm{~mm}$. Our study showed a mean of $1.42 \pm 0.13 \mathrm{~mm}$ root resorption at 5 weeks post canine retraction with $150 \mathrm{~g}$ force while $0.89 \pm 0.04$ $\mathrm{mm}$ with $100 \mathrm{~g}$ force. There were no significant difference $(p>0.05)$ of root resorption between 100 and $150 \mathrm{~g}$ force root at $R_{2}$ and $R_{3}$. Therefore, 100 and $150 \mathrm{~g}$ force using SLB produced similar effect on root resorption.

Chan and Darendeliler (2005) studied the effect of light $(25 \mathrm{~g})$ and heavy $(225 \mathrm{~g})$ forces on premolar that they subsequently extracted. More root resorption found in heavy force compared to light force that was 12 times higher compared with control, whereas with light force it was 3.5 times higher compared to control. In contrast, Rohaya et al. (2011) found no root resorption after 5 weeks post retraction when 100 and $150 \mathrm{~g}$ force were applied to distalise canine using CLB. Another study by Mavragani et al. (2000) concluded that straight wire appliance offered a more gentle and constant force thus reduced the likelihood of root resorption. Meanwhile, Pandis et al. (2008) studied root resorption between SLB and CLB, and found no difference in the amount of root resorption between those two appliance systems with an average root resorption of $1.3 \mathrm{~mm}$. Thus, all previous studies show similar results with no root resorption longer than $2 \mathrm{~mm}$ being observed using SLB.

\section{CONCLUSION}

ALP, TRAP and AST activities in GCF after 100 and $150 \mathrm{~g}$ orthodontic force application were slightly higher than their baseline values. In addition, these two different forces have similar effects in ALP, TRAP and AST activities, root resorption and canine movement. Thus, the bone modeling process after 100 and $150 \mathrm{~g}$ orthodontic force increased slightly. Therefore, SLB usage for canine movement with $100 \mathrm{~g}$ force is as effective as $150 \mathrm{~g}$ force.

\section{ACKNOWLEDGMENTS}

We would like to thank Department of Higher Education, Ministry of Education (MOE), Malaysia for the Grant FRGS/1/2011/SG/UKM/02/13 and ERGS/1/2012/SKK11/ UKM/02/5 and Ministry of Science, Technology and Innovation, Malaysia for the Grant 02-01-02-SF1052. We would also like to thank Universiti Kebangsaan Malaysia for the Grant UKM-DLP-2012-001, UKM-DLP-2012-025 and UKM-DPP-2013-024.

\section{REFERENCES}

Asma, A.A.A., Rohaya, M.A.W. \& Shahrul Hisham, Z.A. 2011 Pattern of crevicular alkaline phosphatase during orthodontic tooth movement: Leveling and alignment stage. Sains Malaysiana 40: 1147-1151.

Asma, A.A.A., Rohaya, M.A.W. \& Shahrul Hisham, Z.A. 2008. Crevicular alkaline phosphatase activity during orthodontic tooth movement: Canine retraction stage. Journal of Medical Sciences 8: 228-233.

Batra, P., Kharbanda, O.P., Duggal, R., Singh, N. \& Prakash, H. 2006. Alkaline phosphatase activity in gingival crevicular fluid during canine retraction. Orthodontics and Craniofacial Research 9: 44-51.

Bhosale, V.,Pushpa,V.H.\& Rajshekhar, C.H. 2011.Histochemical analysis of acid-phosphatase activity incident to orthodontic tooth movement in albino rats - an experimental study. WebmedCentral ORTHODONTICS 2: WMC001653.

Burrow, S.J. 2010. Canine retraction rate with self-ligating brackets vs conventional edgewise brackets. The Angle Orthodontist 80: 626-633.

Chan, E. \& Darendeliler, M.A. 2005. Physical properties of root cementum: part 5. Volumetric analysis of root resorption craters after application of light and heavy forces. American Journal of Orthodontics and Dentofacial Orthopedics 127: 186-195.

Dannan, A., Darwish, M.A. \& Sawan, M.N. 2009. Effect of orthodontic tooth movement on gingival crevicular fluid infiltration; a preliminary investigation. Journal of Dentistry (Tehran) 6: 109-115.

Dudic, A., Kiliaridis, S., Mombelli,A.\& Giannopoulou, C. 2006. Composition changes in gingival crevicular fluid during orthodontic tooth movement: Comparisons between tension and compression sides. European Journal of Oral Science 114: 416-422.

Insoft, M., King, J.G. \& Keeling, S.D. 1996. The measurement of acid and alkaline phosphatase in gingival crevicular fluid during orthodontic tooth movement. American Journal of Orthodontics and Dentofacial Orthopedics 109: 287-295.

Intan Zarina, Z.A., Shahrul Hisham, Z.A., Rohaya, M.A.W., Sahidan, S. \& Zaidah, Z.A. 2008. Osteoclast and osteoblast development of Mus musculus haemopoietic mononucleated cells. Journal of Biological Sciences 8: 506-516.

Kilic, N., Oktay, H. \& Ersoz, M. 2010. Effects of force magnitude on tooth movement: An experimental study in rabbits. European Journal of Orthodontics 32: 154-158.

Kindelan, S.A., Day, P.F., Kindelan, J.D., Spencer, J.R. \& Duggal, M.S. 2008. Dental trauma: An overview of its influence on the management of orthodontic treatment. Part 1. J. Orthod. 35: 68-78.

Lilja, E., Lindskog, S. \& Hammarström, L. 1983. Histochemistry of enzymes associated with tissue degradation incident to orthodontic tooth movement. American Journal of Orthodontics and Dentofacial Orthopaedics 83: 62-75.

Lopatiene, K. \& Dumbravaite, A. 2008. Risk factors of root resorption after orthodontic treatment. Stomatologija 10 : 89-95.

Mavragani, M., Vergari, A., Selliseth, N.J., Bøe, O.E. \& Wisth, P.J. 2000. A radiographic comparison of apical root resorption after orthodontic treatment with a standard edgewise and a straight-wire edgewise technique. European Journal of Orthodontics 22: 665-674. 
Meeran, N.A. 2012. Biological response at the cellular level within the periodontal ligament on application of orthodontic force - An update. Journal of Orthodontic Science 1: 2-10.

Mezomo, M., Lima de Eduardo, S., Macedo de Menezes, L., Weissheimer, A. \& Allgayer, S. 2011. Maxillary canine retraction with self-ligating and conventional brackets. A randomized clinical trial. The Angle Orthodontist 81: 292297.

Pandis, N., Eliades, T., Partowi, S. \& Bourauel, C. 2008. Moments generated during simulated rotational correction with selfligating and conventional brackets. The Angle Orthodontist 78: 1030-1034.

Paolantonio, M., Di Placido, G., Tumini, V., Di Stilio, M., Contento, A. \& Spoto, G. 2000. Aspartate aminotransferase activity in crevicular fluid from dental implants. Journal of Periodontology 71: 1151-1157.

Perinetti, G., Paolantonio, M., Serra, E., D'Archivio, D., D'Ercole, S., Festa, F. \& Spoto, G. 2004. Longitudinal monitoring of subgingival colonization by Actinobacillus actinomycetemcomitans, and crevicular alkaline phosphatase and aspartate aminotransferase activities around orthodontically treated teeth. Journal of Clinical Periodontology 31: 60-67.

Perinetti, G., Paolantonio, M., D’Attilio, M., D’Archivio, D., Dolci, M., Femminella, B., Festa, F. \& Spoto, G. 2003. Aspartate aminotransferase activity in gingival crevicular fluid during orthodontic treatment. A controlled short-term longitudinal study. Journal of Periodontology 74: 145-152.

Perinetti, G., Paolantonio, M., D'Attilio, M., D'Archivio, D., Tripodi, D., Femminella, B., Festa, F. \& Spoto, G. 2002. Alkaline phosphatase activity in gingival crevicular fluid during human orthodontic tooth movement. American Journal of Orthodontics and Dentofacial Orthopedics 122: 548-556.

Ren, Y., Maltha, J.C., Hof, M.A.V.t. \& Kuijpers-Jagtman, A.M. 2004. Optimum force magnitude for orthodontic tooth movement: A mathematic model. American Journal of Orthodontics and Dentofacial Orthopedics 125: 71-77.

Roberts-Harry, D. \& Sandy, J. 2004. Orthodontics. Part 11: Orthodontic tooth movement. Br. Dent. J. 196: 391-394.

Rohaya, M.A.W., Maryati, M.D., Sahidan, S., Asma Alhhusna, A.A., Abdul Aziz, J., Nurfatihah, A.K., Zulham, Y. \& Shahrul Hisham, Z.A. 2011. Crevicular tartrate resistant acid phosphatase activity and rate of tooth movement under different continuous force applications. African Journal of Pharmacy and Pharmacology 5(20): 2213-2219.

Rohaya, M.A.W., Shahrul Hisham, Z.A. \& Khazlina, K. 2008. The activity of aspartate aminotransferase during canine retraction (bodily tooth movement) in orthodontic treatment. Journal of Medical Sciences 8: 553-558.

Ru, N., Liu, S.S., Zhuang, L., Li, S. \& Bai, Y. 2013. In vivo microcomputed tomography evaluation of rat alveolar bone and root resorption during orthodontic tooth movement. The Angle Orthodontist 83: 402-409.

Samuels, R.H., Pender, N. \& Last, K.S. 1993. The effects of orthodontic tooth movement on the glycosaminoglycan components of gingival crevicular fluid. Journal of Clinical Periodontology 20: 371-377.

Seibel, M.J. 2005. Biochemical markers of bone turnover Part I: Biochemistry and variability. The Clinical Biochemist Reviews 26: 97-122.
Shah, A. 2011. Biology of tooth movement. In Orthodontics: Principles and Practice, edited by Pulari, B.S. New Delhi: Jaypee Brothers Medical Publishers (P) Ltd. pp. 219-226.

Shahrul Hisham,Z.A., Yamamoto, Z., Intan Zarina,Z.A., Rohaya, M.A.W. \& Zaida,Z.A. 2011. Cellular and molecular changes in orthodontic tooth movement. The Scientific World Journal 11: $1788-1803$.

Singer, F.R. \& Eyre, D.R. 2008. Using biochemical markers of bone turnover in clinical practice. Cleveland Clinic Journal of Medicine 75: 739-750.

Smale, I., Årtun, J., Behbehani, F., Doppel, D., van’t Hof, M. \& Kuijpers-Jagtman, A.M. 2005. Apical root resorption 6 months after initiation of fixed orthodontic appliance therapy. American Journal of Orthodontics and Dentofacial Orthopedics 128: 57-67.

Stivaros, N., Lowe, C., Dandy, N., Doherty, B . \& Mandall, N.A. 2010. A randomized clinical trial to compare the Goshgarian and Nance palatal arch. European Journal of Orthodontics 32: 171-176.

Tomizuka, R., Shimizu, Y., Kanetaka, H., Suzuki, A., Urayama, S. \& Kikuchi, M. 2007. Histological evaluation of the effects of initially light and gradually increasing force on orthodontic tooth movement. The Angle Orthodontist 77: 410-416.

Yamaguchi, M., Shimizu, N., Shibata, Y. \& Abiko, Y. 1996. Effects of different magnitudes of tension-force on alkaline phosphatase activity in periodontal ligament cells. Journal of Dental Research 75: 889-894.

Rohaya Megat Abdul Wahab* \& Albira Sintian Department of Orthodontics, Faculty of Dentistry Universiti Kebangsaan Malaysia 50300 Kuala Lumpur Malaysia

Zulham Yamamoto, Nurfathiha Abu Kasim, Intan Zarina Zainol Abidin, Sahidan Senafi \& Shahrul Hisham Zainal Ariffin School of Biosciences and Biotechnology

Faculty of Science and Technology

Universiti Kebangsaan Malaysia

43600 Bangi, Selangor D.E.

Malaysia

Zaidah Zainal Ariffin

School of Biology, Faculty of Applied Sciences

Universiti Teknologi MARA

40450 Shah Alam, Selangor D.E.

Malaysia

Zaidah Zainal Ariffin

Atta-ur-Rahman Institute for Natural Product Discovery

Faculty of Pharmacy

Universiti Teknologi MARA

42300 Bandar Puncak Alam, Selangor

Malaysia

*Corresponding author; email: rohaya_megat@ukm.edu.my

Received: 18 April 2014

Accepted: 4 August 2014 